\title{
KOMPETENSI PUSTAKAWAN PERPUSTAKAAN PERGURUAN TINGGI SWASTA (BERBASIS SKKNI) DALAM EKOSISTEM DIGITAL
}

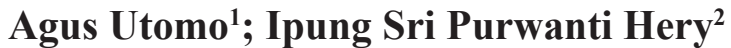 \\ ${ }^{1}$ Prodi Magister Manajemen Sekolah Tinggi Ilmu Ekonomi “Adi Unggul Bhirawa” Surakarta \\ ${ }^{2}$ Perpustakaan PT AUB Surakarta, STIE “Adi Unggul Bhirawa” Surakarta \\ Korespondensi: agus_utomo@stie-aub.ac.id
}

Diajukan: 02-10-2020; Direview: 18-10-2020; Direvisi: 14-12-2020; Diterima: 16-12-2020

\begin{abstract}
The high access to a digital information, requires librarians to innovate, improve competence in the field of technology and work efficiently in order to facilitate the service of exchanging data, communication and uniformity of information. This Librarian Competency Research is a descriptive one to find out how much the readiness of Surakarta Private University (PTS) librarians in responding to the Indonesian National Work Competency Standards (SKKNI). The survey was conducted on 46 librarians at 11 Surakarta Universities. SPSS Software with Sample T-Test is used to analyze data. From the T-Test, showed that $78.3 \%$ of librarians had not taken the Exam, 19.6\% had participated in the training and 2.2\% had failed the competency test. The results of this study are useful as input for leaders of the Surakarta PTS Board of Trustees in fostering and developing the library as an integral part of the Digital Ecosystem in Higher Education. For this reason, it is necessary to study the reasons for the unpreparedness of Surakarta Private University librarians in responding to Competency Test in the Digital Ecosystem.
\end{abstract}

Keywords: information, innovation, competence, digital ecosystem, Surakarta PTS librarian.

\begin{abstract}
ABSTRAK
Tingginya akses informasi digital, menuntut pustakawan melakukan inovasi, meningkatkan kompetensi di bidang teknologi dan efisiensi pekerjaan guna memudahkan pelayaanan pertukaran data, komunikasi maupun keseragaman informasi. Penelitian Kompetensi Pustakawan ini bersifat diskriptif untuk mengetahui seberapa besar kesiapan Pustakawan Perguruan Tinggi Swasta (PTS) Surakarta dalam menyikapi Standar Kompetensi Kerja Nasional Indonesia (SKKNI). Survey dilakukan terhadap 46 pustakawan pada 11 Perguruan Tinggi Surakarta. SPSS Software dengan Sample T-Tes digunakan untuk menganalisis data. Dari Uji -t , menunjukkan bahwa $78,3 \%$ pustakawan belum mengikuti Ujian, $19,6 \%$ pernah mengikuti pelatian dan 2,2\% gagal dalam uji kompetensi. Hasil penelitian ini bermanfaat sebagai masukan bagi pimpinan Badan Musyawarah PTS Surakarta dalam pembinaan dan pengembangan perpustakaan sebagai bagian integral dari Ekosistem Digital pendidikan di Perguruan Tinggi.
\end{abstract}

Kata Kunci: informasi, inovasi, kompetensi, ekosistem digital, pustakawan PTS Surakarta. 


\section{PENDAHULUAN}

Perpustakaan merupakan penyedia informasi dan pelestari bahan pustaka yang berperan penting di dalam bidang pendidikan, penelitian dan pengembangan ilmu pengetahuan, maka di era globalisasi ini dibutuhkan perpustakaan digital dan teknologi informasi supaya pengguna perpustakaan tidak ketinggalan informasi (Al. Purwoko Sunu, 2018). Dinamika informasi di era global menunjukkan bahwa informasi yang diiterima oleh masyarakat merupakan informasi yang berkualitas yaitu informasi yang relevan, tepat dan akurat. Dengan menggunakan jaringan internet sebagai jaringan komunikasi teknologi, pekerjaan yang terkait dengan permasalahan perpustakaan dapat dikerjakan dengan menggunakan salah satu sarana teknologi yakni komputer. Arah perkembangan perpustakaan model digital sudah tentu membawa dampak yang sangat besar dalam hal penyediaan pelayanann. Pustakawan harus dapat memberi pelayanan kepada para pemustaka dibidang kecepatan akses untuk mendapatkan informasi yang lebih tepat dan cepat. Sudah barang tentu agar dapat memenuhi harapan ini, kepiawaian beradaptasi terhadap perkembangan informasi dan teknologi dari para pustakawan sangat diperlukan. Pada saat ini, Ida Fajar Priyanto (2009) menjelaskan umumnya pemustaka mengalami masa kehidupan yang berbeda, saat ini para penustaka sudah melupakan dunia yang baginya dianggap tradisional, pemustaka lahir di era teknologi komputer, dia tumbuh dan berkembang dalam dunia maya, seperti internet yang sangat mempengaruhi perkembangan kehidupan mereka. Mereka sangat terikat dengan teknologi baru yang mengarah kepada penyimpanan informasi instant. Penyimpanan ini dalam bentuk digital format sehingga mereka bisa memodifikasi informasi sesuai dengan yang mereka harapkan.

Apabila masuk ke dalam lingkup perpustakaan, disadari atau tidak saat ini juga telah terjadi perubahan di beragam aspek, misalnya pergeseran pemustaka dari layanan berbasis koleksi ke layanan berbasis pemustaka, kebutuhan informasi cetak ke kebutuhan informasi digital. Jika diidentifikasi, saat ini kita sering mendengar istilah-istilah baru yang berhubungan dengan perkembangan teknologi internet, ada perpustakaan intelligen, pertumbuhan data yang masif, disruptif, big data, mobilisasi pengetahuan, dan lain sebagainya. Kemampuan untuk memberikan informasi yang berkualitas prima menjadi tuntutan wajib bagi pustakawan. Semua membutuhkan pemahaman pustakawan sebagai sumber daya yang berkecimpung di dalam pengelolaan informasi. Permasalahannya adalah "Bagaimana para Pustakawan Perguruan Tinggi Swasta Surakarta Menyikapi Standar Kompetensi Kerja Nasional Indonesia Sebagai Bagian Integral Dalam Ekosistem Perguruan Tinggi?" Penulisan jurnal ini bertujuan untuk mengetahui bagaimanakah kesiapan para pustakawan dalam menyikapi era digital perpustakaan. Selain itu penulisan paper ini juga bertujuan untuk memberikan informasi dan pengetahuan bagi pustakawan dalam menyiasati dirinya menghadapi era Standar Kompetensi Kerja Perpustakaan Nasional Indonesia. (SKKNI) bebasis Digital Ecosystem.

\section{KOMPETENSI PUSTAKAWAN}

Kompetensi adalah kemampuan untuk menguasai pekerjaannya. Pustakawan yang kompeten mampu berkompetitif secara individu maupun secara profesional. Dijelaskan oleh Nanan Khasanah (2008) bahwa ada dua jenis kompetensi yakni (1) Kompetensi individual dan (2) kompetensi profesional. Kedua jenis kompetensi ini harus bersumber pada Standar Kompetensi Kerja Nasional, sebagai acuan dalam peningkatan kualitas pelayanan perpustakaan teruatama di era digitalisasi, dimana pustakawan dituntut 
untuk mampu menguasai pekerjaan sebagai tanggung jawabnya. Pustakawan harus selalu meningkatkan motivasi, mengupgrade keterampilan serta konsisten terhadap tanggung jawab yang diembannya berdasarkan standar yang ditetapkan. Lebih jauh Nanan Khasanah menegaskan bahwa kompetensi individu, memberikan gambaran tentang kemampuan pribadi seorang pustakawan yang menyatu dalam bentuk keterampilan, perilaku dan nilai yang dimiliki pustakawan tersebut. Dengan perilaku yang dijiwai nilai-nilai kejujuran, maka ketrampilan untuk bekerja secara efektif, menjadikan dirinya sebagai komunikator yang baik. Seorang pustakawan yang memiliki jiwa komunikator akan mampu bertahan dan menyesuaikan diri dalam setiap perubahan dan perkembangan terkait dengan pekerjaannya, karena dia senantiasa menilai lebih terhadap pengetahuan yang dihadapinya. Kearifan sifatnya yang selalu berfikir positif, mudah menyesuaikan diri dalam setiap perubahan menjadikan kompetensi individu menjadi partner yang baik dalam setiap proses aktivitas seorang pustakawan. Selanjutnya kompetensi profesional terkait dengan pengetahuan pustakawan dalam bidang informasi, teknologi, manajemen dan penelitian. Kemampuan pustakawan menggunakan pengetahuan sebagai dasar untuk menyediakan layanan perpustakaan secara profesional. Kompetensi profesional merupakan hal penting yang harus di miliki oleh pustakawan dalam membangun suatu perpustakaan digital. Ketrampilannya dalam bidang teknologi informasi harus bisa bersaing dengan kompetensi yang lain melalui komitmen belajar sehingga pengembangan pendidikan dapat berkesinambungan. Untuk itu Uji Kompetensi Pustakawan berbasis SKKNI perlu diupayakan bagi peningkatan kualitas individu dan profesional pustakawan dapat terpenuhi.

\section{STANDAR KOMPETENSI KERJA NASIONAL INDONESIA (SKKNI).}

Luthfiati Makarim (2019) menjelaskan bahwa, Proses pemberian Sertifikat Kompetensi Kerja yang dilakukan secara sistematis dan obyektif melalui uji kompetensi yang mengacu kepada standar kompetensi kerja nasional Indonesia, standar internasional dan/atau standar khusus. Proses pemberian Sertifikat Kompetensi Kerja Profesi Pustakawan yang dilakukan secara sistematis dan obyektifmelalui uji kompetensi yang mengacu kepada Standar Kompetensi Kerja Nasional Indonesia(SKKNI) Nomor 83 Tahun 2012 Bidang Perpustakaan. Tujuannya adalah untuk memastikan dan memelihara kompetensi yang telah dimiliki melalui proses pembelajaran, baik formal, nonformal, pelatihan kerja, atau pun pengalaman kerja. Dalam dunia kerja, kompetensi harus dipelihara. Tidak boleh pernah kompeten, tetapi kompeten dan terus tetap kompeten. Lebih jauh ia menegaskan Sertifikat Kompetensi Pustakawan ini ada masa berlaku dan ada surveilan. Sedangkan pelaksana Sertifikasi Profesi Pustakawan adalah Lembaga Sertifikasi Profesi (LSP) Pustakawan. Hal ini untuk menjamin kredibilitas dan konsistensinya, LSP Pustakawan harus mendapat lisensi dari BNSP (Badan Nasional Sertifikasi Profesi). Dalam Sertifikasi Kompetensi ini terdapat 7 komponen yaitu : (1) Standar kompetensi kerja, (2) Skema sertifikasi kompetensi pustakawan (3) Asesor kompetensi, (4) Peserta sertifikasi, (5) Materi uji kompetensi, (6) Tempat uji kompetensi dan (7) Biaya uji kompetensi.

\section{PUSTAKAWAN, KETRAMPILAN DAN PERANNYA DALAM DIGITAL EKOSISTEM}

Dalam Perpustakaan Digital

Pustakawan merupakan spesialis yang profesional di bidang informasi. Pustakawan dalam digital perpustakaan selayaknya dapat mengelola perpustakaan secara digital. Mampu 
mengkombinasikan perencanaan dan data mining secara profesional. Disamping itu pustakawan digital ini harus tangguh dalam menelusuri penggalian ilmu dan pengetahuan. Secara profesional senang memberikan layanan rujukan digital maupun layanan digital informasi. Nanan Khasanah (2008) menambahkan bahwa pustakawan di era digital perpustakaan menjadi representasi informasi, petugas ekstraksi, pembagi informasi, dan mengkoordinasikannya dalam sajian data berbasis internet dalam kemudahan akses dan penelusuran multimedia. Kesimpulan uraian ini adalah bahwa pustakawan harus dinamis dalam memainkan peran sebagai penyaji informasi. Pemakai atau pemustaka membutuhkan kecepatan dan ketepatan dalam mengakses informasi untuk keperluan pendidikan, pelatihan serta pengembangan karier dalam tugasnya. Oleh karena itu tugas seorang pustakawan digital hampir sama dengan tugas pustakawan pada bagian pengolahan bahan pustaka. Bedanya pustakawan digital lebih kearah persiapan penyediaan informasi yang dibutuhkan oleh para pemustaka melalui digital storage dan digital preservasi serta pembuatan katalog maupun digital code clasification.

\section{Ketrampilan Pustakawan Digital.} Jonak Tukatsz, et al, (2016) menegaskan bahwa seorang pustakawan harus mempunyai pengetahuan dan keterampilan digital, diantaranya kemampuan internet, agar pustakawan ini mampu mengelola perpustakaan digital. Kemampuan mengelola rangkaian jaringan komputer besar dan kecil yang luas dan saling berhubungan melalui jaringan, itulah internet. Jaringan internet, tambah Jonak Tukatsz membagi (tele)-komunikasi yang ada di seluruh dunia dan menjadikan dunia sebagai area yang mudah diakses oleh siapapun. Fasilitas internet diantaranya adalah (1) Surat elektronik (e-mail) yaitu layanan yang paling banyak dipakai dan digunakan untuk hal apapun sebagaimana orang menggunakan telepon atau berkirim surat, Yang ke (2) adalah pemanggilan informasi dengan alat yang disebut komputer. Pada umumnya komputer mempunyai file-file informasi yang bebas untuk didiskusikan dan dibicarakan. File-file tersebut berupa berbagai perangkat lunak yang sangat hebat yang berasal dari US Supreme Court, teks bukubuku kuno, katalog-katalog kartu perpustakaan serta gambar-gambar. yang ke (3) yang biasanya disebut WWW (World Wide Web) yang menggabungkan teks, gambar, suara dan bahkan animasi. Web ini memungkinkan kita berpindah-pindah dengan hanya mengklik mouse. Site-site web tumbuh lebih cepat dan site-site baru lainnya bermunculan setiap saat. (4) Buletin board atau disebut usenet. Usenet merupakan buletin board yang terdistribusi secara muksimal melalui online dan memiliki kurang lebih 700 juta karakter pesan diatas 12.000 kelompok topik berbeda yang muncul setiap hari. (5) Games dan gosip. Fasilitas game yang tersedia adalah MUD (Multi Use Dungeon). Internet Relay Chat (IRC) adalah saluran dimana para pengguna dapat melangsungkan percakapan dengan pengguna lain di berbagai belahan dunia.

\section{Peran Pustakawan Dalam Digital}

Ekosistem. Ekosistem Digital adalah metafora ekosistem, Jonak Tukatsz, dkk (2016) mengungkap sejumlah fitur yang menjadi ciri dunia sosial modern yang secara menyeluruh ditransformasikan oleh teknologi digital. Komunitas organisme yang beragam yang dikenal sebagai ekosistem alami saling berhubungan dan saling tregantung karena unsur-unsur ini terpatri secara kompleks dalam jaringan materi dan transfer energi. Peningkatan serupa dalam keanekaragaman entitas yang membentuk dunia sosial serta untuk pertumbuhan kompleksitas hubungan timbal balik diantara warga dalam sosial media tersebut dapat dikontrol oleh teknologi digital ini. Pustakawan dalam era Ekosistem Digital sangat diharapkan mampu mengakselerasikan 
dirinya menjadi bagian integral guna memberikan pelayanan yang optimal kepada para pemustaka. Pustakawan sangat berperan sebagai partner pemustaka dalam melakukan penelusuran haruslah dilakukan dengan cara yang cepat dan tepat serta akurat. Banyaknya informasi yang terpapar di dunia maya dapat menjadikan informasi tersebut kurang bermanfaat bahkan mungkin bisa menjadi informasi yang menyesatkan serta menimbulkan berita hoak, sehingga pustakawan harus selektif, serta melakukan cek dan ricek sebelum meneruskan informasi tersebut kepada penggunanya. Jadi pustakawan yang kompeten dan handal sangat penting peranannya dalam memberi dan memamarkan informasi penting yang dibutuhkan oleh pengguna perpustakaan digital di era Digital Ekosistem saat ini. Disamping sumber daya manusia yang handal Yusuf Kalla (2018) menegaskan bahwa perpustakaan sebagai institusi harus mampu menjadi pusat strategis sebagai tempat untuk belajar, mendapatkan informasi dan inovasi serta rekreasi.

\section{METODOLOGI, HASIL PENELITIAN}

\section{DAN PEMBAHASAN}

\section{Metodologi}

Matriks 1

DATA PERPUSTAKAAN PTS SURAKARTA ZONA UTARA

\begin{tabular}{|c|c|c|c|c|c|}
\hline No & Nama Perpustakaan & $\begin{array}{c}\text { Jumlah } \\
\text { Pustakawan } \\
\end{array}$ & Ijazah & & Masa Kerja \\
\hline 1 & $\begin{array}{l}\text { Perpustakaan } \\
\text { PT AUB Surakarta }\end{array}$ & 4 & $\begin{array}{l}\text { Ahli Madya Perpustakaan } \\
\text { PhD Sastra }\end{array}$ & $\begin{array}{l}3 \\
1\end{array}$ & 1-2 Tahun \\
\hline 2 & $\begin{array}{l}\text { Perpustakaan } \\
\text { UTP Surakarta }\end{array}$ & 7 & $\begin{array}{l}\text { Ahli Madya Perpustakaan } \\
\text { S2 Perpustakaan } \\
\text { S3 Pertanian \& SMA }\end{array}$ & $\begin{array}{l}2 \\
1 \\
4\end{array}$ & 3-7 Tahun \\
\hline 3 & $\begin{array}{l}\text { Perpustakaan } \\
\text { STIE ATMABAKTI } \\
\text { Surakarta }\end{array}$ & 2 & $\begin{array}{l}\text { S1 Perpustakaan } \\
\text { D3 Akuntansi }\end{array}$ & $\begin{array}{l}1 \\
1\end{array}$ & 2-7 Tahun \\
\hline 4 & $\begin{array}{l}\text { Perpustakaan } \\
\text { Univ Kristen Surakarta }\end{array}$ & 1 & Ahli Madya Perpustakaan & 1 & 2 Tahun \\
\hline 5 & $\begin{array}{l}\text { Perpustakaan } \\
\text { Univ. Duta Bangsa } \\
\text { Surakarta }\end{array}$ & 3 & $\begin{array}{l}\text { Ahli Madya Perpustakaan } \\
\text { S1 Perpustakaan }\end{array}$ & $\begin{array}{l}3 \\
1\end{array}$ & 3-7 Tahun \\
\hline 6 & $\begin{array}{l}\text { Perpustakaan } \\
\text { Univ. Islam Batik (UNIBA) } \\
\text { Surakarta }\end{array}$ & 3 & $\begin{array}{l}\text { Ahli Madya Perpustakaan } \\
\text { S2 Hukum }\end{array}$ & $\begin{array}{l}2 \\
1\end{array}$ & 2-7 Tahun \\
\hline 7 & \begin{tabular}{|l} 
Perpustakaan \\
Univ. Slamet Riyadi \\
(UNISRI) Ska. \\
\end{tabular} & 5 & $\begin{array}{l}\text { S1 Perpustakaan } \\
\text { S1 Lainnya }\end{array}$ & $\begin{array}{l}4 \\
1\end{array}$ & 5 Tahun \\
\hline 8 & $\begin{array}{l}\text { Perpustakaan } \\
\text { USAHID Surakarta }\end{array}$ & 2 & $\begin{array}{l}\text { Ahli Madya Perpustakaan } \\
\text { Sarjana Ekonomi }\end{array}$ & $\begin{array}{l}1 \\
1\end{array}$ & 2-3 Tahun \\
\hline
\end{tabular}




\begin{tabular}{|c|c|c|c|c|}
\hline 9 & $\begin{array}{l}\text { Perpustakaan } \\
\text { STIKES Aisyiyah } \\
\text { Surakarta }\end{array}$ & 5 & $\begin{array}{l}\text { Ahli Madya Perpustakaan } \\
\text { S2 Perpustakaan }\end{array}$ & 3-5 Tahun \\
\hline 10 & $\begin{array}{l}\text { Perpustakaan } \\
\text { Univ Setya Budi (USB) } \\
\text { Surakarta }\end{array}$ & 6 & $\begin{array}{l}\text { Ahli Madya Perpustakaan } \\
\text { S2 Perpustakaan } \\
\text { Lain2 }\end{array}$ & 3-10 Tahun \\
\hline 11 & $\begin{array}{l}\text { Perpustakaan } \\
\text { POLTEKES Surakarta }\end{array}$ & 8 & $\begin{array}{l}\text { Ahli Madya Perpustakaan } \\
\text { S1 Perpustakaan } \\
\text { S2 Perpustakaan }\end{array}$ & 5-10 Tahun \\
\hline & JUMLAH PUSTAKAWAN & 46 & & \\
\hline
\end{tabular}

Catatan: D3 Perpust: $21 \quad$ S1 Perpust: $11 \quad$ S2 Perpust: $4 \quad$ S3 Non Pustaka: 2 Lain2: 8

Penelitian ini bersifat descriptive dengan menggunakan semi structured interview questionair sebagai instrumen untuk mengumpulkan data. Sampel secara random ditetapkan sejumlah 46 pustakawan yang semuanya bertugas di 10 Perpustakaan Perguruan Tinggi Swasta dan 1 Perpustakaan Perguruan Tinggi Negri di Surakarta Zona Utara. Sampel yang seluruhnya 46 orang terdiri atas 36 pustakawan berijazah D3, S1 dan S2 Perpustakaan dan 10 lainnya berijazah Non Perpustakaan. Matriks 1 menyajikan data selengkapnya terkait dengan sampel yang meliputi Nama Perpustakaan, Jumlah Pustakawan, Ijazah dan Masa Kerja. Sementara itu, instrumen yang digunakan untuk mengumpulkan data survey berupa semi structured interview questions, yang kebenaran hasilnya telah di trianggulasikan kepada Pimpinan Perpustakaan masing-masing, disajikan dalam Matriks 2 dalam lampiran 1.

\section{HASILPENELITIANDANPEMBAHASAN}

Data yang telah terkumpul dianalisis dengan SPSS Sofware melalui Uji-t, yang selanjutnya disajikan dalam Tabel 1 (One Sample Statistics), Tabel 2 ( One-Sample Test) dan Tabel 3
Tabel 1

\begin{tabular}{|l|c|c|c|c|}
\hline & N & Mean & $\begin{array}{c}\text { Std. } \\
\text { Deviation }\end{array}$ & $\begin{array}{c}\text { Std. } \\
\text { Error } \\
\text { Mean }\end{array}$ \\
\hline $\begin{array}{l}\text { Jumlah } \\
\text { Pustakawan }\end{array}$ & 46 & 3,78 & 1428 &, 211 \\
\hline Ijazah & 46 & 3,93 &, 929 &, 137 \\
\hline Masa Kerja & 46 & 4,20 & 1003 &, 148 \\
\hline $\begin{array}{l}\text { Uji } \\
\text { Kompetensi }\end{array}$ & 46 & 2,24 &, 480 &, 071 \\
\hline Ijazah Kepala & 46 & 3,70 & 1459 &, 215 \\
\hline
\end{tabular}

Diskripsi Tabel 1 menunjukkan nilai ratarata variable Jumlah pustakawan, Ijazah yang dimiliki, masa kerja, uji kompetensi dan ijazah yang dimiliki oleh pimpinan perpustakaan. Indikator yang digunakan dalam analisa ini dikategorikan menjadi 2 yakni kategori kurang dan kategori baik, dengan skala likert 5 maka Nilai mean $<2,5$ masuk dalam kategori kurang, sedangkan Nilai mean $>2,5$ dikategorikan baik. Kecuali Variable Uji Kompetensi yang dalam hal ini masuk dalam kategori kurang, Tabel 1 menunjukkan bahwa keempat variable lainnya masuk dalam kategori baik. Artinya bahwa kondisi Perpustakaan Perguruan Tinggi Swasta di Surakarta Zone Utara secara umum dapat dikatakan baik

(Uji Kompetensi) berikut: 
Tabel 2

One-Sample Test

\begin{tabular}{|c|c|c|c|c|c|c|}
\hline & \multicolumn{6}{|c|}{ Test Value $=0$} \\
\hline & \multirow[b]{2}{*}{$t$} & \multirow[b]{2}{*}{$\mathrm{df}$} & \multirow[b]{2}{*}{ Siq. (2-tailed) } & \multirow{2}{*}{$\begin{array}{c}\text { Mean } \\
\text { Difference }\end{array}$} & \multicolumn{2}{|c|}{$\begin{array}{l}95 \% \text { Confidence } \\
\text { Interval of the } \\
\text { Difference }\end{array}$} \\
\hline & & & & & Lower & Upper \\
\hline Jumlah Pustakawan & 17,959 & 45 &, 000 & 3,783 & 3,36 & 4,21 \\
\hline ljazah & 28,739 & 45 & ,000 & 3,935 & 3,66 & 4,21 \\
\hline Masa Kerja & 28,381 & 45 &, 000 & 4,196 & 3,90 & 4,49 \\
\hline Uji Kompetensi & 31,636 & 45 &, 000 & 2,239 & 2,10 & 2,38 \\
\hline $\begin{array}{l}\text { ljazah Kepala } \\
\text { Perpustakaan }\end{array}$ & 17,184 & 45 &, 000 & 3,696 & 3,26 & 4,13 \\
\hline
\end{tabular}

Tabel 2 menyajikan analisis signifikansi variable terhadap keberhasilan perpustakaan dan kompetensi pustakawan. (1) Variable Jumlah Pustakawan menunjukkan nilai minimal 3,36 dan nilai maksimal 4,21 yang berarti jumlah pustakawan memenuhi kategori baik dan berpengaruh secara signifikan terhadap keberhasilan perpustakaan. Demikian juga dengan variable (2) ijazah pustakawan, (3) masa kerja dan (5) ijazah pimpinan, masing-masing memiliki nilai minimal $(3,66$, 3,90 dan 3,26 serta nilai tertinggi 4,21, 4,49 dan 4,13). Yang berarti bawa ketiga variable ini juga bermakna baik dan berpengaruh secara signifikan terhadap keberhasilan lembaga perpustakaan masing-masing. Untuk Variable (4) Uji Kompetensi , nilai tertinggi tercatat masih kurang. Ini berarti sebagian besar pustakawan yang bertugas di Perpustakaan Perguruan Tinggi Swasta di Surakarta Zona Utara belum mengikuti Uji Kompetensi, apalagi memiliki Sertifikat Kompetensi Kerja Nasional Indonesia (SKKNI) sebagai penopang keprofesionalitas tugas para pustakawan ini

Tabel 3

\begin{tabular}{|rl|r|r|r|r|}
\multicolumn{7}{|c|}{ Uji Kompetensi } \\
\hline & & & & & Cumulative \\
& & Frequency & Percent & ValidPercent & Percent \\
\hline Valid & 2 & 36 & 78,3 & 78,3 & 78,3 \\
& 3 & 9 & 19,6 & 19,6 & 97,8 \\
& 1 & 2,2 & 2,2 & 100,0 \\
& Total & 46 & 100,0 & 100,0 & \\
\hline
\end{tabular}

Tabel 3 ini diolah khusus untuk menegaskan analisis Uji Kompetensi dari $\mathrm{N}$
(46) pustakawan di 11 Perpustakaan Perguruan Tinggi Swasta di Surakarta Zone Utara. Sesuai dengan kriteria yang digunakan dalam Skala Likkert 1-5, didapatkan 36 personil atau 78,3\% memperoleh nilai 2 yang berarti kesiapan pustakawan dalam menyikapi Uji KKNI dinyatakan cukup. Mereka mempunyai minat untuk mengikuti Ujian ini. Selanjutnya 9 pustakawan atau 19,6\% memperoleh nilai 3 yang berarti kesembilan personil tersebut sudah pernah mengikuti pelatihan Ujian. Sementara itu ada 1 (satu) personil atau 2,2\% yang mendapatkan nilai 4 . Ini berarti personil tersebut sudah pernah mengikuti ujian namun gagal memperoleh serifikat. Beberapa faktor penyebab kegagalan ini antara lain disebabkan karena kurangnya pemahaman terhadap proses pelaksanaan ujian SKKNI ini. Selain hal tersebut para pustakawan merasa keberatan harus meninggalkan tugas untuk pergi mengikuti ujian di Jakarta dengan biaya yang cukup mahal, yang antara lain meliputi biaya transportasi, akomodasi dan biaya lainnya yang harus ditanggung sendiri oleh para pustakawan.

\section{SIMPULAN DAN SARAN}

Kompetensi Pustakawan Perpustakaan Perguruan Tinggi Swasta Surakarta (Berbasis SKKNI) Dalam Ekosistem Digital mengisyaratkan bahwa sebagian besar pustakawan yang memiliki ijazah Ahli Madya, Sarjana maupun Master dalam Perpustakaan belum mengikuti Ujian, namun mereka sangat 
berminat dan ingin mempersiapkan diri mereka dalam menyikapi Standard Kompetensi Kerja Nasional Indonesia (SKKNI). Hal ini terlihat dari kajian dan hasil uji T-Test terhadap 46 pustakawan Perguruan Tinggi Swasta di Surakarta yang menunjukkan bahwa 78,3\% pustakawan belum mengikuti Ujian, 19,6\% pernah mengikuti pelatian dan 2,2\% sudah mengikuti uji kompetensi namun gagal. Kendala yang dihadapi oleh sebagian besar pustakawan disebabkan karena kurangnya pemahaman terhadap proses pelaksanaan ujian SKKNI ini. Sementara itu beberapa pustakawan yang berminat untuk mengikuti ujian ini, dua diantaranya pernah mengikuti Ujian dan belum berhasil. Selain hal tersebut para pustakawan merasa keberatan harus meninggalkan tugas untuk pergi mengikuti ujian di Jakarta dengan biaya yang cukup mahal.

Untuk itu diharapkan agar Badan Musyawarah Perguruan Tinggi Swasta (BM PTS) Surakarta, melalui pimpinan perguruan tinggi masing-masing memberikan motivasi dan memfasilitasi terlaksananya Ujian SKKNI. Untuk dapat menjadi bagian yang integral dalam era Digital Ekosistem, pustakawan digital professional layak memiliki kompetensi yang memenuhi standard nasional, namun karena mahalnya biaya yang harus dibayarkan, maka apabila dimungkinkan, BM PTS Surakarta bekerjasama dengan Perpustakaan Nasional Jakarta mensponsori terlaksananya Ujian SKKNI di Surakarta.

\section{DAFTAR PUSTAKA}

Al. Purwoko Sunu, 2018; Peran Perpustakaan Digital Dan Teknologi Informasi Di Era Globalisasi, Pustakawan Universitas Sanata Dharma, Yogyakarta

Fatmawati, E: 2018 ; Disruptif Diri Pustakawan Dalam Menghadapi Era Revolusi Industri 4.0 Jurnal Iqra' Volume $12 \mathrm{No.01} \mathrm{Mei}$ 2018
Gujarati, Damodar N, 2006: Ekonometrika Buku 1, Erlangga, Jakarta

Hartono, 2017; Strategi Pengembangan Perpustakaan Digital Dalam Membangun Aksesibilitas Informasi: Sebuah Kajian Teoritis Pada Perpustakaan Perguruan Tinggi Islam Di Indonesia , Jurnal Perpustakaan Vol. 8 No.1 Tahun 2017: 75-91 ISSN 1979 - 9527

Ida Fajar Priyanto, 2009. Membangun Kompetensi Pustakawan Terhadap Pengembangan Perpustakaan Digital. Universitas Gajah Mada Yogyakarta.

Jonak Tukatsz, et al, 2016; Digital Ecosystems Society in the Digital Age, University of Warsawa

Luthfiati Makarim, 2019; SKKNI Nomor 83 Tahun 2012 Bidang Perpustakaan, Lembaga Sertifikasi Profesi (LSP) Pustakawan Bimbingan Teknis Kompetensi Pengelola Perpustakaan PTS di Lingkungan Kopertis Wilayah VI Tahun 2018, Hotel Quest Semarang, Jawa Tengah 23 - 24 Juli 2019

Nanan, Khasanah, 2008. Kompetensi Pustakawan di Era Perpustakaan Digital, Disampaikan Dalam Pelatihan Perpustakaan Digital Untuk Pustakawan di Lingkungan PMPTK se Indonesia di Institute Teknologi Bandung.

Pallant, J. 2011. SPSS Survival Manual $4^{\text {th }}$ Edition: A Step By Step Guide To Data Analysis Using SPSS Version 18. Maidenhead, Birkshire; Open University Press. Retrieved on from http://www. Indiana.edu/statmath.

RTS Tiara Hilda, 2017; Pustakawan Professional di Era Digital, Jurnal Kepustakawanan dan Masyarakat Membaca Vol. 33 (2) (2017) 059-066 Palembang 
Ulfah Andayani, 2018; Strategi Pengembangan Pustakawan Akademik Sebagai Blended Librarian Dalam Penyediaan Layanan Perpustakaan Di Era Keilmuan Digital, Al-Maktabah, Volume 17, Desember 2018

\section{Lampiran:}

Matriks 2

SEMI STRUCTURED INTERVIEW QUESTIONAIR

\section{Kompetensi Pustakawan Perpustakaan Perguruan Tinggi Swasta Surakarta (Berbasis SKKNI) Dalam Ekosistem Digital}

\begin{tabular}{|c|c|c|c|}
\hline No & Pertanyaan & Jawaban & Kriteria Jawaban \\
\hline 1 & $\begin{array}{l}\text { Berapakan Jumlah Pustakawan di } \\
\text { Perpustakaan Saudara? }\end{array}$ & $\begin{array}{l}\text { a. } 2 \\
\text { b. } 3 \\
\text { c. } 4 \\
\text { d. } 5 \\
\text { e. }>5\end{array}$ & $\begin{array}{ll}\text { a. } \text { Kurang } & =1 \\
\text { b. } \text { Cukup } & =2 \\
\text { c. } \text { Normal } & =3 \\
\text { d. } \text { Baik } & =4 \\
\text { e. } & \text { Sangat Baik }=5\end{array}$ \\
\hline 2 & $\begin{array}{l}\text { Rata2 Pustakawan di perpustakaan Saudara, } \\
\text { berijazah apa? }\end{array}$ & $\begin{array}{l}\text { a. SMA } \\
\text { b. D3 } \\
\text { c. Sarjana Lainya } \\
\text { d. D3 Perpustakaan } \\
\text { e. S1 Perpustakaan }\end{array}$ & $\begin{array}{ll}\text { a. } \text { Kurang } & =1 \\
\text { b. } \text { Cukup } & =2 \\
\text { c. } \text { Normal } & =3 \\
\text { d. } \text { Baik } & =4 \\
\text { e. Sangat Baik }=5\end{array}$ \\
\hline 3 & $\begin{array}{l}\text { Sudah berapa lama Saudara bekerja di } \\
\text { Perpustakaan ini? }\end{array}$ & $\begin{array}{l}\text { a. }<6 \text { bulan } \\
\text { b. } 1 \text { tahun } \\
\text { c. } 2 \text { tahun } \\
\text { d. } 3 \text { tahun } \\
\text { e. }>3 \text { tahun }\end{array}$ & $\begin{array}{ll}\text { a. } \text { Kurang } & =1 \\
\text { b. } \text { Cukup } & =2 \\
\text { c. } \text { Normal } & =3 \\
\text { d. } \text { Baik } & =4 \\
\text { e. } & \text { Sangat Baik }=5\end{array}$ \\
\hline 4 & $\begin{array}{l}\text { Apakah Saudara sudah mengikuti ujian dan } \\
\text { mempunyai SKKPNI? }\end{array}$ & $\begin{array}{l}\text { a. Tidak tau SKKNI } \\
\text { b. Belum } \\
\text { c. Akan mengikuti ujian } \\
\text { d. Sudah tapi tidak lulus } \\
\text { e. Sudah dan mempunyai } \\
\text { SKKPNI }\end{array}$ & $\begin{array}{ll}\text { a. } \text { Kurang } & =1 \\
\text { b. } \text { Cukup } & =2 \\
\text { c. } \text { Normal } & =3 \\
\text { d. } \text { Baik } & =4 \\
\text { e. } \text { Sangat Baik }=5\end{array}$ \\
\hline 5 & $\begin{array}{l}\text { Berijasah apakah Kepala Perpustakaan } \\
\text { Saudara? }\end{array}$ & $\begin{array}{l}\text { a. D3 } \\
\text { b. Sarjana Lainya } \\
\text { c. D3 Perpustakaan } \\
\text { d. S1 Perpustakaan } \\
\text { e. S2, S3 Perpustakaan }\end{array}$ & $\begin{array}{ll}\text { a. } \text { Kurang } & =1 \\
\text { b. } \text { Cukup } & =2 \\
\text { c. } \text { Normal } & =3 \\
\text { d. } \text { Baik } & =4 \\
\text { e. } & \text { Sangat Baik }=5\end{array}$ \\
\hline
\end{tabular}

